Article

\title{
Phylogenetic Diversity of Trichoderma Strains and Their Antagonistic Potential against Soil-Borne Pathogens under Stress Conditions
}

\author{
Omar A. Hewedy $1,2, * \mathbb{C}$, Khalid S. Abdel Lateif ${ }^{2,3}$, Mahmoud F. Seleiman $4,5, * \mathbb{1}$, \\ Ashwag Shami ${ }^{6}$ (D), Fawziah M. Albarakaty ${ }^{6,7}$ and Rasha M. El-Meihy ${ }^{8,9, *(D)}$ \\ 1 Department of Plant Agriculture, University of Guelph, 50 Stone Road East, Guelph, ON N1G 2W1, Canada \\ 2 Department of Genetics, Faculty of Agriculture, Menoufia University, Shibin El-Kom 32514, Egypt; \\ k_dein2001@yahoo.com \\ 3 Department of Biotechnology, College of Science, Taif University, Taif 21944, Saudi Arabia \\ 4 Plant Production Department, College of Food and Agriculture Sciences, King Saud University, \\ P.O. Box 2460, Riyadh 11451, Saudi Arabia \\ 5 Department of Crop Sciences, Faculty of Agriculture, Menoufia University, Shibin El-kom 32514, Egypt \\ 6 Biology Department, College of Sciences, Princess Nourah bint Abdulrahman University, Riyadh 11617, \\ Saudi Arabia; AYShami@pnu.edu.sa (A.S.); fmbarakati@uqu.edu.sa (F.M.A.) \\ 7 Department of Biology, College of Applied Sciences, Umm AlQura University, \\ Makkah Al Moukarramh 21955, Saudi Arabia \\ 8 Department of Agricultural Microbiology, Faculty of Agriculture, Benha University, Moshtohor 13736, Egypt \\ 9 School of Chemistry, Chemical Engineering and Life Science, Wuhan University of Technology, \\ Wuhan 430070, China \\ * Correspondence: ohewedy@uoguelph.ca (O.A.H.); mseleiman@ksu.edu.sa (M.F.S.); \\ rashaelmehy@fagr.bu.edu.eg (R.M.E.-M.)
}

Received: 21 June 2020; Accepted: 17 July 2020; Published: 23 July 2020

\begin{abstract}
Trichoderma species are known as excellent biocontrol agents against soil-borne pathogens that cause considerable crop losses. Eight strains of Trichoderma were isolated from five Egyptian regions. They identified based on translation elongation factor- $1 \alpha$ (TEF1) sequencing as four different Trichoderma species: Trichoderma asperellum, Trichoderma harzianum, Trichoderma viride, and Trichoderma longibrachiatum. Optimal growth conditions (temperature and media), and the phosphate solubilization capability of Trichoderma strains were evaluated in vitro. Further, the ability of these strains to antagonize Fusarium solani, Macrophomina phaseolina, and Fusarium graminearum was also evaluated. The results revealed that Trichoderma harzianum (Th6) exhibited the highest antagonistic ability against F. solani, M. phaseolina and F. graminearum with inhibition rates of $71.42 \%$, $72.97 \%$, and $84.61 \%$, respectively. Trichoderma viride (Tv8) exhibited the lowest antagonism against the same pathogens with inhibition rates of 50\%, 64\% and 69.23\%, respectively. Simple-sequence repeats (SSRs) and random amplified polymorphic DNA (RAPD) markers were used to evaluate the genetic variability of the Trichoderma strains. The results revealed that of 45 RAPD amplified bands, 36 bands $(80 \%)$ were polymorphic and of SSRs amplified 36 bands, 31 bands $(86.11 \%)$ were polymorphic. The amplification of calmodulin and $\beta$-1,3-endoglucanase was noted at $500 \mathrm{bp}$ and $230 \mathrm{bp}$, respectively. Data indicated that $T$. viride (Tv8) had the highest phosphate solubilization index $(10.0 \mathrm{~mm})$, while T. harzianum (Th6) had the lowest phosphate solubilization index $(4.0 \mathrm{~mm})$. In conclusion, T. harzianum (Th6) had the highest antagonistic activity in dual culture assay along with the growth rate; while T. viride (Tv8) had the highest phosphate solubilization activity. There are still gaps in obtaining new formulations, selecting potent Trichoderma strains to confirm disease control in planta. For improving Trichoderma recommendation in the organic agricultural system and sustaining the fertility of the soil, the field application of highly antagonistic biocontrol agents in different types of soil and plant species will be the first approach toward bio-pesticide treatments along with bio-fertilizer inoculation.
\end{abstract}


Furthermore, secondary metabolites will be investigated for the most promising strains with the combination of different pathogens and application timing.

Keywords: Trichoderma; antagonism; RAPD; SSR; TEF1 sequencing; phosphate solubilization; diversity

\section{Introduction}

Plant health and crop production are constantly under threat from biotic constraints, especially fungal diseases caused by various species of soil fungal pathogens. Even though farmers believe that chemical fungicides can control these diseases, some already use them in combination biological control agents. These are of great attention as pesticides have unfavorable side impacts, and it is necessary to find an alternative method such as beneficial microbes to prevent human and environmental disasters. Trichoderma is a soil fungal genus of great economic importance which is ubiquitous under various climatic conditions [1] and has the ability to live in soil stress conditions for instance salinity, alkalinity, nutrient deficiency and drought [2]. Several Trichoderma species are beneficial to host plants, providing one of the most promising alternatives for promoting plant growth [3] by increasing the plant health and its immunity, motivating mechanisms of plant defense, avoiding pathogen outbreaks and controlling plant disease [4,5]. In particular, T. harzianum [6]; T. asperellum [7]; T. asperelloides [8]; T. virdie [9], and T. longibrachiatum [10] are promising biological control agents against soil-borne pathogens that suppress plant health. Trichoderma spp. plays an essential role through pathogens inhibition under the contact zone due to its multiple biocontrol mechanisms such as mycoparasitism, antibiosis, competition for sites and nutrients [11], availability of metals [12], non-volatile and volatile compounds production [13], extracellular hydrolytic enzymes production [7], and pathogen's enzymes inactivation [14]. Biotic and abiotic factors influence antagonistic activity and growth of Trichoderma species against pathogens, including growth medium [6,15], temperature [16] and metal availability [17]. Trichoderma strains use several modes of action, including acidification, chelation, reduction, and hydrolysis to regulate the availability of metals such as phosphate and iron solubilization. Although Trichoderma can live under different environmental conditions, temperature plays a substantial function in enhancing its growth and mycoparasitic activity [18-20]. The harmful pathogenic fungi that Trichoderma can inhibit include, Fusarium solani [21], F. graminearum [22], and Macrophomina phaseolina [23]. Understanding biodiversity is important for determining biological resources and sustainable development.

Theoretically, morphological taxonomy of Trichoderma is primarily based on macro. and micro-morphological characteristics which includes colony color, shape, size, appearance on specific culture media, and spore-forming structures. However, the greatest reliable method to identify an unidentified isolate at the taxon level by molecular approaches is by phylogenetic analysis [24]. This molecular identification is important for the precise identification of Trichoderma species, and it is challenging to distinguish Trichoderma fungi by traditional identification methods using only morphological characterization $[25,26]$. To discover diverse Trichoderma species, it is imperative to have reliable phylogenetic information, and more precise molecular methods have substituted traditional identification approaches in most taxonomic investigation. The internal transcribed spacer (ITS) is considered the universal fungal molecular barcode, but it cannot distinguish numerous closely interrelated species and has low species resolution in the genus Trichoderma [24]. Taxonomic Trichoderma communities need to develop specific practices for molecular characterization in their identification. Partial translation elongation factor 1-alpha (TEF1) sequences have been suggested for the phylogenetic analysis of such genus to assess the accuracy and robustness of DNA barcoding and to discover previously undescribed species [27]. 
Various authors have reported that TEF1 has a high phylogenetic efficacy because of: (i) it is more relative to the identification of unknown species; and (ii) it is alienable among Trichoderma species [28-30].

Not surprisingly, the sequencing of ITS and/or TEF1 has been extensively studied [10,31-33], reference databases make it possible to submit DNA sequences of environmental isolates and link sequence data to phenotypic data. In particular, molecular DNA markers are employed as a reliable tool to determine the genetic diversity and relationships [34,35]. RAPD is one of the valuable markers which has been utilized to determine the biodiversity of Trichoderma species, due to its use in identifying mysterious genomes and its requirement of only limited quantities of DNA [36-41]. SSR has likewise been proved to be a robust marker to investigate polymorphism and discriminate between different species of Trichoderma [42-44].

Another important gene encodes calmodulin, which plays a pivotal role in the antifungal ability of Trichoderma and its hyphal growth rate, serving as one of the critical antagonistic mechanisms to compete with fungal pathogens. Calmodulin can be involved in the formation of germinative tubes, and play a role in fungal growth, developmental structures, and differentiation [45].The expression of many genes is regulated by certain physiological events, i.e., growth on different media (with glucose) or by starving the cells of different amino acids. These regulatory proteins are a complex system and involve a variety of regulated proteins.

Furthermore, they depend on the function of signal transduction pathways to link between the extracellular signal such as nutrients, environmental conditions and the transcriptional response expression [46]. One of these regulatory proteins was studied in this investigation by amplification of calmodulin ( $\mathrm{cal}$ ) gene to prove the linkage between the abiotic stress (nutrients and temperature) and the viability of growth rate and sporulation among Trichoderma strains under these stressful conditions. The presence of calmodulin has been detected in Trichoderma viride. It affected the vegetative growth and starvation-induced conidiation of T. viride significantly and it is necessary for both fungal dimorphism and mycelial growth [47].

The aims of this investigation were to evaluate the genetic diversity among eight strains of Trichoderma obtained from different geographic locations of Egypt based on RAPD and SSR markers and their antigenic activity against soil-borne pathogens under stress conditions to gain a better understanding of how Trichoderma spp. enhance its defense systems under stressful conditions. Besides, phosphate solubilization capability of Trichoderma strains were investigated.

\section{Materials and Methods}

This research consisted of eight experiments conducted in 2019. The molecular work was conducted at the Laboratory of Biotechnology, Horticulture Research Institute, Agricultural Research Center, Giza, Egypt. The antifungal activity, along with phosphate solubilizing experiments, were carried out at the Department of Agricultural Microbiology. Faculty of Agriculture, Benha University, Egypt.

\subsection{Trichoderma Strains}

Eight Trichoderma strains previously isolated from different Egyptian locations and identified using the internal transcribed spacer (ITS) [10] were used in this study. These strains were belonged to four species, including T. asperlum (Ta), T. harzianum (Th), T. longibrachiatum (Tl), and T. viride (Tv); coded as described in [10].

\subsection{Pathogenic Fungi}

Three pathogenic fungi, Fusarium solani, Macrophomina phaseolina, and Fusarium graminearum were grown on potato dextrose agar (PDA) at $28^{\circ} \mathrm{C}$, then maintained at $4{ }^{\circ} \mathrm{C}$ for further experiments. These pathogens were obtained from the Plant Pathology Research Institute, ARC, Egypt. 


\subsection{TEF1 Sequencing for Identification of Trichoderma Strains}

The present work was derived from previous phylogenetic analysis and identification of 15 strains [10]. To confirm the previous ITS identification of the fungal strains, the TEF1 region was amplified using two primers (Eurofins) named EF1-728F (5'CATCGAGAAGTTCGAGAAGG3') and TEF1 $R$ (5'GCCATCCTTGGAGATACCAGC3') as previously described $[48,49]$.

PCR reactions of the TEF1 region were amplified in a total volume of $20 \mu \mathrm{L}$ reaction mixture; $0.5 \mu \mathrm{L}$ each of both forward and reverse primers $(10 \mathrm{pmol} / \mu \mathrm{L}), 1.0 \mu \mathrm{L}$ of purified DNA $(10 \mathrm{ng} / \mu \mathrm{L})$, $10 \mu \mathrm{L}$ of $2 \times$ PCR Master Mix buffer and $8 \mu \mathrm{L}$ of ultrapure sterile water by Applied Biosystems ${ }^{\mathrm{TM}}$ SimpliAmp ${ }^{\mathrm{TM}}$ Thermal Cycler (Catalog No.A24811). Detection of PCR products was carried out by loading $5 \mu \mathrm{L}$ of each sample onto a 1.8\% agarose gel alongside a GeneRuler 100 bp DNA Ladder (catalog no.SM0241). The PCR products were Sanger-sequenced by the Big-Dye Terminator v3.1 sequencing kit in a total volume of $20 \mu \mathrm{L}$ with a 3730xl automated sequencer (Applied Biosystems, Foster City, CA, USA). Nucleotide sequences were determined on both strands of the PCR amplification products at the Macrogen sequencing facility (Macrogen Inc., Seoul, Korea). The phylogenetic tree of the TEF1 gene was then built using MEGA version 7 software to show the similarity of Trichoderma strains. The sequences of the TEF1 fragments were analyzed using the nucleotide BLASTn program, and the National Center for Biotechnology Information (NCBI) database was used to test for similarity with known Trichoderma strains in combination with TrichOKey v. 2.0 http://www.isth.info/ [50].

\subsection{Evaluation of the Genetic Diversity of Trichoderma Strains}

To study the phylogenetic relationship between the eight antifungal strains, seven sets of PCR primers for each of two different molecular markers (SSR [42,44], RAPD) was used as shown in Table 1.

Table 1. Design of species-specific $\beta-1,3$-endoglucanase, microsatellite loci and random primers used in this study for the identification of Trichoderma spp. and its genetic relationships

\begin{tabular}{|c|c|}
\hline Primer Name & Primer Sequence $\left(5^{\prime}-3^{\prime}\right)$ \\
\hline \multicolumn{2}{|r|}{ RAPD } \\
\hline OPA02 & TGCCGAGCTG \\
\hline OPA04 & AATCGGGCTG \\
\hline OPA05 & AGGGGTCTTG \\
\hline OP-A3 & AGTCAGCCAC \\
\hline OP-B3 & CATCCCCCTG \\
\hline OP-B9 & TGGGGGACTC \\
\hline $\mathrm{OP}-\mathrm{C} 3$ & GGGGGTCTTT \\
\hline \multicolumn{2}{|r|}{ SSR $[42,44]$} \\
\hline SSR1 & F: GAAACAACACCGAAATACAC, R: CAAGTCAGATGAAGTTTG \\
\hline SSR2 & F: GACTCATACTTTGTTCTTAGCAG, R: GAACGGAGCGGTCACATTAG \\
\hline SSR3 & F: CAAGCTGACGCCTATGAAGA, R: CTTTCACTCACTCAACTCTC \\
\hline SSR6 & F: CCATGCATACGTGACTGC, R: GTTGACTGTTGGTGTAAGTG \\
\hline SSR8 & F: GGGAATTTGTGGAGGGAAG, R: CCTCAGAATGTCCCTGTC \\
\hline TvCTTT29 & F: GGAAGATAGCACGATGAAGTCG, R: AACCGTGGAAGTAGGTGTCG \\
\hline TvCAT32 & F: GTGTAGCAGCCCAACAGTCC, R: CAGGTGTCGTGACAGATTCG \\
\hline$\beta$-1,3-endoglucanase & F:TCAACATCGCCAACGTCAACGAC, R: TGCCAATACGGGAACCAGTGATC \\
\hline
\end{tabular}

\subsubsection{RAPD Analysis of Trichoderma Strains}

All the fungal species were cultured on $50 \mathrm{~mL}$ of PDA at $28^{\circ} \mathrm{C}$ for $96-120 \mathrm{~h}$ in the dark. Then, Genomic DNA was extracted from the collected fungal mycelium using a spin column method (Qiamp mini kit, Qiagen $\mathrm{GmbH}$, Hilden, Germany) with slight modifications as previously described [51]. The PCR amplification reaction of the purified DNA samples was performed in a total volume of $25 \mu \mathrm{L}$ mixture as previously described [52]. The amplification reaction was carried out in a thermal cycler (catalog no. A24811) programmed with a slight modification of the amplification cycles; 5 min 
at $94{ }^{\circ} \mathrm{C}$ for the initial denaturation followed by 35 cycles, each consisting of a denaturation step of $1 \mathrm{~min}$ at $94^{\circ} \mathrm{C}$, an annealing step for $1 \mathrm{~min}$ at $32-36^{\circ} \mathrm{C}$ depending on the primers, and an elongation step for $2 \mathrm{~min}$ at $72{ }^{\circ} \mathrm{C}$ with a final extension for $10 \mathrm{~min}$ at $72{ }^{\circ} \mathrm{C}$. Amplified PCR products were separated by electrophoresis with $2 \%$ agarose gels containing ethidium bromide and visualized under ultraviolet light.

\subsubsection{SSR Analysis of Trichoderma Strains}

The SSR amplification reactions were conducted in a total volume of $50 \mu \mathrm{L} ; 25 \mathrm{ng}$ of DNA template, $1 \times$ PCR buffer, $25 \mu \mathrm{L}$ MyTaq ${ }^{\mathrm{TM}}$ Red Mix, $8 \mu \mathrm{L}$ DNA Template, $1 \mu \mathrm{L}$ each of the forward and reverse primers $(10 \mathrm{pmol} / \mu \mathrm{L})$, and $15 \mu \mathrm{L}$ nuclease-free water. For the SSR markers, PCR conditions began with an initial denaturation for $3 \mathrm{~min}$ at $95^{\circ} \mathrm{C}$, followed by 35 cycles of denaturation for $15 \mathrm{~s}$ at $94{ }^{\circ} \mathrm{C}$, annealing for $45 \mathrm{~s}$ at $52-56{ }^{\circ} \mathrm{C}$ depending on the primers, and the extension for $1 \mathrm{~min}$ at $72{ }^{\circ} \mathrm{C}$, with a final extension for $10 \mathrm{~min}$ at $72{ }^{\circ} \mathrm{C}$. These PCR products were migrated in $1.5 \%$ agarose gel in $0.5 \times$ TBE buffer at $90 \mathrm{~V}$ for $90 \mathrm{~min}$ with a $1000 \mathrm{bp}$ DNA ladder as a size marker. The gel was stained with ethidium bromide $(0.5 \mu \mathrm{g} / \mathrm{mL})$ and visualized under a gel documentation system.

\subsection{Specific Trichoderma Genes}

\subsubsection{Calmodulin (cal) Gene}

Based on the highest and lowest growth rate of different Trichoderma strains, four strains (Ta1, Th4, Th6 and Tv8) were used to detect (cal) gene for testing the optimal growth conditions (temperature and media). Calmodulin gene (cal) was amplified according to previously published protocol [53].

\subsection{2. $\beta$-1,3-endoglucanase}

The primer design and PCR amplification of $\beta-1,3$-endoglucanase were performed as previously described [54].

\subsection{Activities of Trichoderma Strains under Stress Conditions}

\subsubsection{Growth under Thermal Stress and Different Substrates}

In this experiment, the ability of Trichoderma strains to grow at different temperatures below and above the optimum temperature was estimated using two incubation temperatures $\left(25^{\circ} \mathrm{C}\right.$ and $35^{\circ} \mathrm{C}$ ) along with two different growth media: PDA and cornmeal dextrose agar (CMD) [55]. PDA was composed of infusion from $200.0 \mathrm{~g} / \mathrm{L}$ potatoes, $20.0 \mathrm{~g} / \mathrm{L}$ dextrose, and $15.0 \mathrm{~g} / \mathrm{L}$ agar, with a final $\mathrm{pH}$ of $5.6 \pm 0.2$, whereas CMD was composed of infusion from $50.0 \mathrm{~g} / \mathrm{L}$ cornmeal, $2.0 \mathrm{~g} / \mathrm{L}$ dextrose, and $15.0 \mathrm{~g} / \mathrm{L}$ agar, with a final $\mathrm{pH}$ of $6.0 \pm 0.2$.

For each strain, a 5-mm disk was separately inoculated at the centre of 90-mm Petri dishes containing $10 \mathrm{~mL}$ of each medium. The number of replications for each treatment was three. All Petri dishes were divided into two groups; the first was incubated at $25^{\circ} \mathrm{C}$ and the second was incubated at $35^{\circ} \mathrm{C}$. Mycelial growth was recorded after seven days [14].

\subsubsection{Ability to Solubilize Insoluble Phosphate}

The assay was modified from previously described method $[8,56]$ to test the ability of Trichoderma strains for phosphate solubilization. Briefly, each strain was singly cultured on a Petri dish $(100 \mathrm{~mm})$ containing $10 \mathrm{~mL}$ of NBRIP agar composed of $10.0 \mathrm{~g} / \mathrm{L}$ glucose, $5.0 \mathrm{~g} / \mathrm{L} \mathrm{MgCl} 2 \cdot 6 \mathrm{H}_{2} \mathrm{O}, 0.25 \mathrm{~g} / \mathrm{L}$ $\mathrm{MgSO}_{4} \cdot 7 \mathrm{H}_{2} \mathrm{O}, 0.2 \mathrm{~g} / \mathrm{L} \mathrm{KCl}, 0.002 \mathrm{~g} / \mathrm{L} \mathrm{FeSO} \cdot 7 \mathrm{H}_{2} \mathrm{O}, 0.5\left(\mathrm{NH}_{4}\right)_{2} \mathrm{SO}_{4}, 0.5 \mathrm{~g} / \mathrm{L}$ yeast extract, $10.0 \mathrm{~g} / \mathrm{L}$ tri-calcium phosphate $\left(\mathrm{Ca}_{3} \mathrm{HPO}_{4}\right)$, and $15.0 \mathrm{~g} / \mathrm{L}$ Bacto-agar, dissolved in $950 \mathrm{~mL}$ distilled water with the $\mathrm{pH}$ adjusted to 7.2. Glucose was separately filter sterilized and mixed with autoclaved medium. The dishes were inoculated with a 5-mm fungal disk, then incubated at $28 \pm 0.2{ }^{\circ} \mathrm{C}$ for seven days. Then, Trichoderma plates were examined for a clear zone around the colonies. The diameter of these $\mathrm{P}$ 
solubilization zones was measured and calculated by applying the formula for phosphate solubilization index (PSI) [57].

$$
\text { PSI }=\frac{\text { colony diameter }+ \text { halo zone diameter }}{\text { colony diameter }}
$$

\subsubsection{The Antifungal Ability of Trichoderma Strains against Soil-Borne Pathogenic Fungi}

Trichoderma strains were evaluated against three soil-borne pathogens; Fusarium solani, Macrophomina phaseolina, and Fusarium graminearum by a dual culture technique as previously published [58]. Briefly, 5-mm diameter mycelial disks from the edge of 7 days-old cultures of Trichoderma fungi and the soil-borne pathogens were simultaneously cultured on the opposite of the plate at an equal distance from the margin. The experimental design was completely randomized with four replications for each strain along with the control plates (which had no Trichoderma). Inoculated Petri dishes $(90 \mathrm{~mm})$ were incubated at $28^{\circ} \mathrm{C}$. The antagonistic activity was estimated after 5-7 days of incubation by measuring the radius $(\mathrm{mm})$ of the pathogen colony in the control plate (R1) and the radius of the pathogen colony in the direction of the antagonist colony (R2). The inhibition percent of mycelial growth (PIMG) was calculated formulas described by [59,60]:

$$
\operatorname{PIMG}(\%)=\frac{\mathrm{R} 1-\mathrm{R} 2}{\mathrm{R} 1} \times 100
$$

where: $\mathrm{R} 1$ = radial growth of pathogen in control plate, $\mathrm{R} 2=$ radial growth of pathogen in dual culture plate.

\subsubsection{Rate and Speed of Growth}

All Trichoderma strains and F. graminearum were grown at the same time on PDA and observed daily to record their growth.

\subsection{T. harzianum (Th6) against F. graminearum}

\subsubsection{Mycoparasitic Activity at Different Temperatures}

This experiment was separated into three groups; the first was incubated at $4{ }^{\circ} \mathrm{C}$, the second at $28^{\circ} \mathrm{C}$, and the last at $37^{\circ} \mathrm{C}$. All Petri dishes were incubated for five days and checked daily for mycoparasitic activity.

\subsubsection{Slide Culture Method}

The T. harzianum (Th6) and F. graminearum interaction was visualized using light microscopy (Olympus BX61, Tallahassee, FL, USA) as the procedure described [61]. Then, each Trichoderma-pathogen hyphae contact was observed on a thin PDA film on the slide. The hyphae interactive zones were cut into pieces at different growth rates, which were then observed directly under a light microscope for the presence of coiling structures form wall disintegration.

\subsection{Statistical Analysis}

Data were statistically analyzed using analysis of variance and comparisons of means at a $5 \%$ level of significance with a Duncan's multiple range test analysis performed with one-way analysis of variance using IBM SPSS Statistics v25.0 software. Amplicons were scored for their presence (1) or absence (0) in each strain. Cluster analysis of the binary data was performed using the NTSYS-pc v.2.1 program [62]. Similarity matrices were generated using Jaccard's coefficients, and an unweighted pair-group method using arithmetic averages (UPGMA) was chosen to generate the dendrogram from the RAPD and SSR similarity matrices. 


\section{Results and Discussion}

\subsection{Molecular Experiments}

\subsubsection{TEF1 Gene for Confirming the Identification of Trichoderma Strains}

The molecular identification of strains based on the previously described ITS sequences [10] and the fragment of the TEF1 gene confirmed that all of the strains used in this study belong to four Trichoderma species.

PCR amplification of the TEF1 region gave one band of approximately $610 \mathrm{bp}$. The PCR products were sequenced and, the data compared with the reference data on NCBI using BLASTn. A tree containing eight strains of Trichoderma was drawn; the tested strains were found to be closed to four taxa of Trichoderma belonging to T. harzianum (Th3, Th4, Th6 and Th7), two strains were classified as T. asperellum (Ta1 and Ta2), one strain was identified as T. longibrachiatum (Tl5), and, one strain belonged to T. viride (Tv8) (Figure 1). The phylogenetic tree of Trichoderma species based on TEF1 sequences divided the strains into two major clusters. The first cluster included the strains Th4, Th6, Th7, Tv8 and Tl5, while the second cluster contained the strains Ta1, Ta2 and Th3 (Figure 1). The diversity of the phylogenetic analysis between ITS and TEF1 markers is understandable as each marker targets different genomic regions. A previously study [63] investigated the biodiversity of Trichoderma spp. using both ITS and TEF1 regions and found that TEF1 has enough variations to discriminate between different species of Trichoderma. Our results agree with previous studies, highlighting the effectiveness of TEF1 marker for the identification and discrimination of different Trichoderma species [31-33].

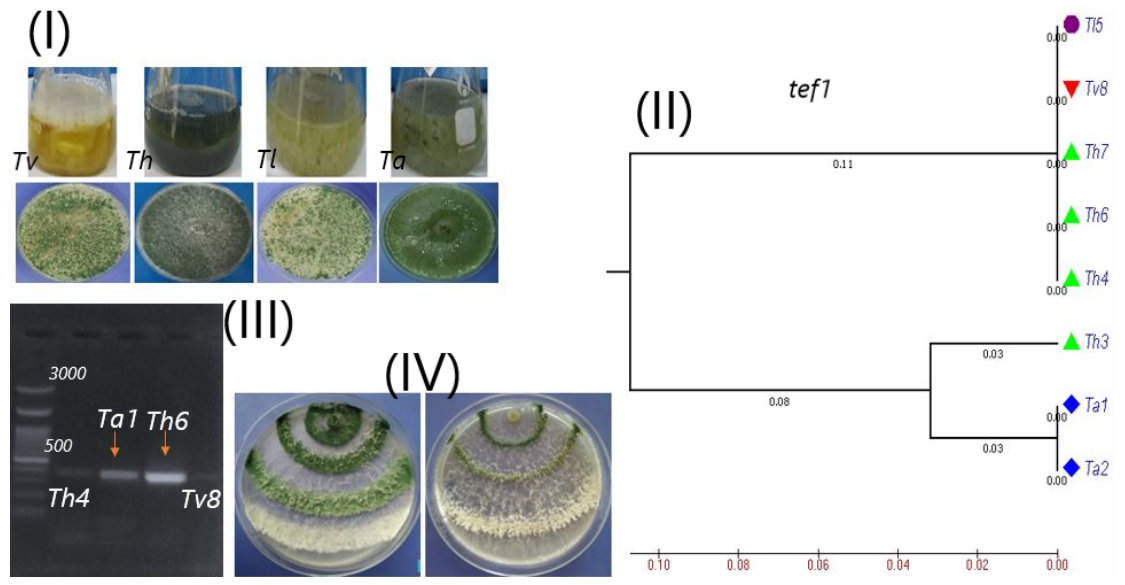

Figure 1. (I) Trichoderma species used in this study. (II) Phylogenetic tree of the identified isolates based on the TEF1 sequences dataset. The numbers below the branches indicate bootstrap values. (III) Calmodulin gene (cal) detection in the strains with the highest (Ta1, Th6) and the lowest (Th4, Tv8) growth rate test. (IV) The growth rate of Trichoderma strains on different growth media. Ta1 = Trichoderma asperlum; Ta2 = Trichoderma asperlum; Th3 = Trichoderma harzianum; Th4 = Trichoderma harzianum; Tl5 = Trichoderma longibrachiatum; Th6 = Trichoderma harzianum; Th7 = Trichoderma harzianum; Tv8 = Trichoderma viride.

The amplification of two specific genes (cal and $\beta$-1,3-endoglucanase) was noted at 500 bp and $230 \mathrm{bp}$, respectively (Figure 1III). In agreement with previous studies, $\beta-1,3$-endoglucanase is an important gene with an essential role in encoding cell wall degrading enzymes (CWDE) and is induced by metabolites secreted by Trichoderma under biotic stress. Furthermore, it plays a vital role in the mycoparasitic activity against the pathogens, especially soil-borne pathogens, after the interaction contact [64-66].

Considering the other important gene, the calmodulin signaling pathway plays an essential role in the conidiation and hyphal growth of Trichoderma fungi. It might be considered the main cytoskeleton component for regulation of nuclear transcription factors that affect the expression level of other genes. 
The diversity of Trichoderma strains is noted to include different species that can vary from each other in their phenotypic characterization, including growth rate, conidium morphology and biogeography. Molecular analysis utilizing fragments of calmodulin genes indicates phenotypic characteristics typical of Trichoderma strains.

A previous study [67] concluded that external $\mathrm{Ca}^{2+}$ induced growth-independent cellulase production, hyphal growth, and total protein secretion of T. reesei Rut-C30 via the $\left(\mathrm{Ca}^{2+} / \mathrm{calmodulin}\right)$ signal transduction pathway. Thus, our results might be used for more efficient chitinase and $\beta$-1,3-endoglucanase enzymes production by T. asperellum (Ta1) and T. harzianum (Th6), as well as providing a suitable approach to understand the regulatory mechanisms due to environmental interactions.

\subsubsection{RAPD Analysis of Trichoderma Strains}

A set of seven decamer RAPD primers was used for further evaluation of genetic diversity of the eight Egyptian Trichoderma strains (Ta1, Ta2, Th3, Th4, Tl5, Th6, Th7 and Tv8). A total of 45 bands were obtained by PCR; $36(80 \%)$ of these produced polymorphic patterns among tested strains (Table 2). The number of polymorphic bands ranged from four (OP-A3, OPA04 and OP-B9) to eight (OPA05). The highest similarity value (0.91) was found between isolates $T h 7$ and $T v 8$, while the lowest similarity value (0.53) was found between two pairs of isolates (Ta1 and Th3; Ta1 and Th6). RAPD amplicons were scored for their absence and presence, and 36 bands differentiating strains were used to build a binary matrix, and then a dendrogram showing genetic diversity (Figure 2). The cluster analysis divided the strains into two groups; the first group contained the strains (Ta2, Th3, Th4, Tl5, Th6, Th7 and Tv8) while, the second group contained only the strain Ta1. Interestingly, the strains Th3, Th4, Th6 and Th7 were found in the same group, while, the strains of $\mathrm{Ta} 1$ and $\mathrm{Ta} 2$ were classified into separate groups. These results are consistent with previous work [68] which studied the polymorphisms of cultivated peanut genotypes using the SCOT marker and found that not all strains related to the same variety were classified in the same group. In addition, another study [39] indicated that the RAPD marker revealed a genetic diversity among T. asperellum isolates. In our work, the UPGMA dendrogram illustrated that T. asperellum isolates could not be grouped by their lytic enzymes production and/or antifungal activity. Previous studies employed the RAPD marker to evaluate the genetic relationships between different Trichoderma isolates and the results indicated high level of polymorphisms [39-41,69,70].

Table 2. RAPD and SSR-PCR analysis of Trichoderma strains.

\begin{tabular}{|c|c|c|c|c|}
\hline Primers & Band Size (bp) & $\begin{array}{l}\text { Total Number } \\
\text { of Bands }\end{array}$ & $\begin{array}{c}\text { Number of } \\
\text { Polymorphic Bands }\end{array}$ & $\begin{array}{c}\text { Polymorphic Bands } \\
\text { Percentage (\%) }\end{array}$ \\
\hline \multicolumn{5}{|c|}{ RAPD } \\
\hline OPA02 & $200-3000$ & 9 & 6 & 66.6 \\
\hline OPA04 & $100-2500$ & 6 & 4 & 66.6 \\
\hline OPA05 & $250-3000$ & 9 & 8 & 88.88 \\
\hline OP-A3 & $400-1500$ & 5 & 4 & 80 \\
\hline OP-B3 & $100-1300$ & 5 & 5 & 100 \\
\hline OP-B9 & 200-1000 & 4 & 4 & 100 \\
\hline $\mathrm{OP}-\mathrm{C} 3$ & 100-1300 & 7 & 5 & 71.4 \\
\hline Total & $\ldots \ldots$ & 45 & 36 & $-\ldots$ \\
\hline \multicolumn{5}{|c|}{ SSR } \\
\hline SSR1 & $100-500$ & 6 & 5 & 83.3 \\
\hline SSR2 & $100-500$ & 5 & 4 & 80 \\
\hline SSR3 & $100-500$ & 5 & 4 & 80 \\
\hline SSR6 & $100-500$ & 5 & 4 & 80 \\
\hline SSR8 & $100-500$ & 4 & 3 & 75 \\
\hline Tvc-29 & $100-400$ & 5 & 5 & 100 \\
\hline Tvc-32 & $100-400$ & 6 & 6 & 100 \\
\hline Total & $\ldots$ & 36 & 31 & - . . - . - \\
\hline
\end{tabular}



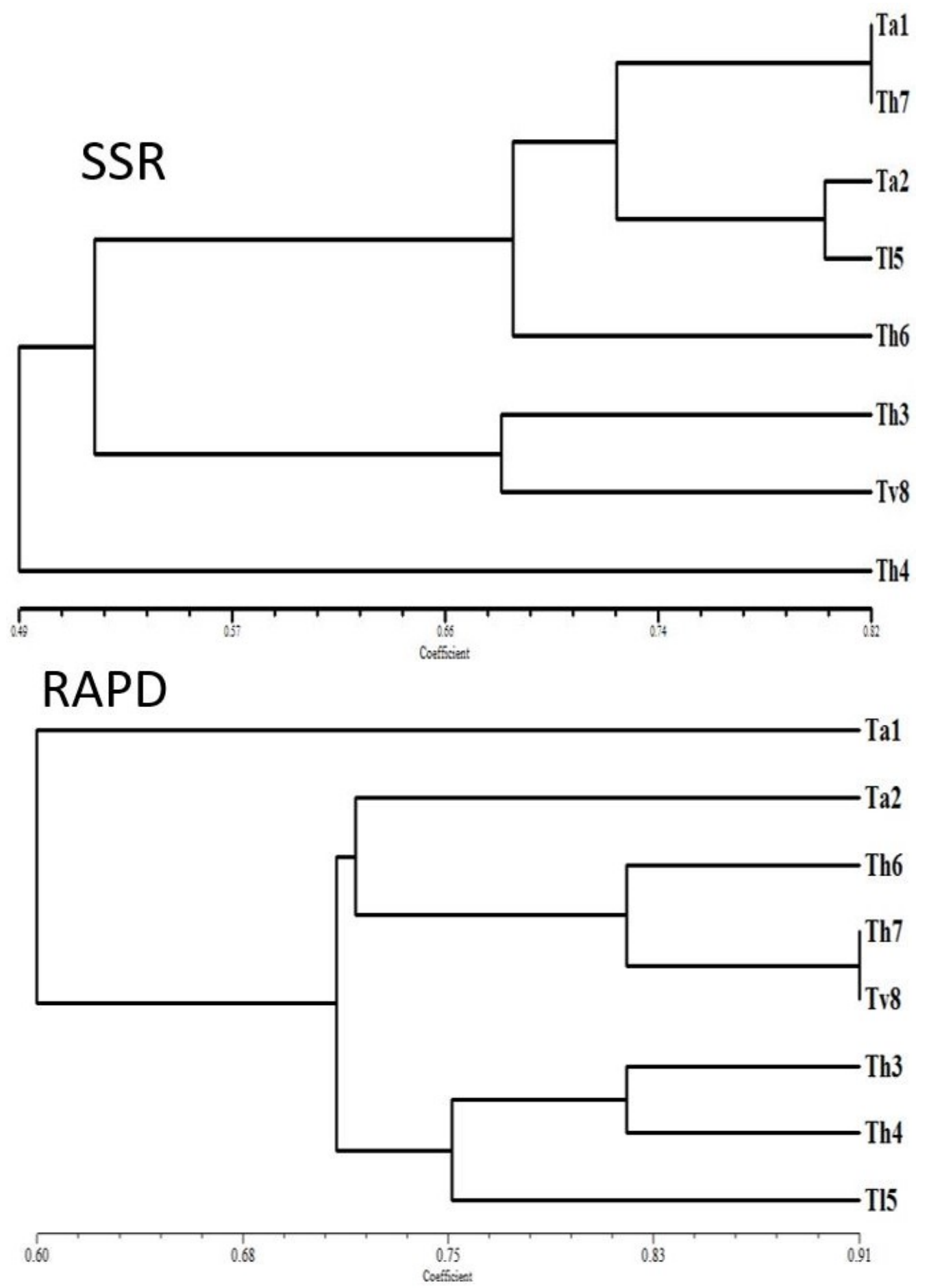

Figure 2. Dendrogram based on Jaccard's similarity coefficients scored from RAPD and SSR data using the UPGMA algorithm representing 8 Trichoderma strains (Ta1, Ta2, Th3, Th4, Th6, Th7, Tl5 and Tv8). Ta1 $=$ Trichoderma asperlum; Ta2 = Trichoderma asperlum; Th3 = Trichoderma harzianum; Th4 = Trichoderma harzianum; Tl5 = Trichoderma longibrachiatum; Th6 = Trichoderma harzianum; Th7 = Trichoderma harzianum; $T$ 8 $8=$ Trichoderma viride.

\subsubsection{SSR Analysis of Trichoderma Strains}

A total of 36 bands were detected, out of which 31 (86\%) were polymorphic bands (Table 2). The number of polymorphic bands for each strain was three (SR8) to six (TvCAT32). The highest value of similarity (0.82) was noted between strains Th7 and Ta1. In contrast, the lowest similarity value (0.35) 
was found between the strains $T h 3$ and $T h 7$ (Table 2). The cluster analysis divided the strains into two main groups; the first group contained the strains (Ta1, Ta2, Th3, Tl5, Th6, Th7 and Tv8) while, the second group contained only the strain Th4. Interestingly, all the strains of T. asperillum and T. harizianum were found together in the same cluster. In general, SSR markers exhibited more polymorphism than RAPD markers and both markers established specific genetic relationships between strains. The variability in the polymorphisms and cluster analysis obtained with SSR and RAPD markers is understandable since each marker amplifies different genomic regions. An earlier study [42] investigated the genetic variability among different Trichoderma strains using SSRs and RAPD markers and found that more polymorphisms are obtained with SSRs ( $>77 \%)$ than with RAPD ( $50 \%)$. Moreover, another study [43] compared the occurrence of SSRs in T. atroviride, T. harzianum, T. reesei, and T. virens and revealed that the occurrence, abundance, and density of microsatellites differed among the different species of Trichoderma. This highlights the efficacy of SSR markers in establishing new genetic relationships between the different strains of Trichoderma.

\subsection{Activities of Trichoderma Strains under Stress Conditions}

\subsubsection{Growth under Thermal Stress and Different Substrates}

Trichoderma growth relies on the balance between nutrients and substrates to promote conidiation, although identification of the optimal growth conditions requires further research. Of the physical parameters, temperature plays the most critical role in enhancing fungal growth. In addition to temperature, a previous study reported that the carbon and nitrogen $(\mathrm{C}: \mathrm{N})$ ratio influences conidiation in Trichoderma growth [71].

In this experiment, Trichoderma strains were grown on two growth media (PDA and CMD) and incubated at two temperatures to estimate their ability to grow under thermal stress. The data presented in Table 3 indicate that all tested Trichoderma strains were able to grow on different media but at various growth rates. The Trichoderma strains showed a distinct variation in their phenotypic characteristics depending on the culture media, with a clear difference in the morphological growth patterns between PDA and CMD media. The growth rate at $25^{\circ} \mathrm{C}$ for all strains except for Tv 8 and Th3 was higher on PDA than CMD except for Th6. At $25^{\circ} \mathrm{C}$ on PDA, Ta1 and Tv 8 had the highest and lowest growth rates, respectively, and on CMD, Th6 and Th4 had the highest and lowest growth rates, respectively. Several studies have claimed that potato dextrose medium is the best choice for the growth of Trichoderma fungi $[6,14,15,72]$. One study [73] evaluated the growth of $T$. harzianum on five culture media namely, PDA, modified potato dextrose agar, water agar (WA), carrot agar (CA) and cornmeal agar (CMA), PDA and WA were found to be more and less effective for growth, respectively. In another study, wheat bran was found to be the best medium out of four media tested, including PDA, for Trichoderma spp. growth [74].

On the other hand, at $35^{\circ} \mathrm{C}$, the growth rate for all strains except for Th3 and Th4 strains was higher on PDA than CMD. The data in Table 3 show that Th6 had the highest growth rate on both media, and that Th4 and Tv8 had the lowest growth rate on PDA and CMD, respectively. This might be due to the different components in the two media and the potato extract in PDA that provide the essential elements for fungi growth. Moreover, $25^{\circ} \mathrm{C}$ was the best incubation temperature for all Trichoderma strains regardless of the medium used for growth. Similar results by another group [75] proved that $25^{\circ} \mathrm{C}$ promotes more mycelial growth of T. harzianum than $15^{\circ} \mathrm{C}$. Another group, Ref [19] observed an increase in the mycelial growth of all Trichoderma isolates at temperatures ranging from 12 ${ }^{\circ} \mathrm{C}$ to $27^{\circ} \mathrm{C}$, and then decreased up to $37^{\circ} \mathrm{C}$, being inhibited at $42^{\circ} \mathrm{C}$.

Moreover, another study [18] showed that all Trichoderma species grew at different temperatures $20^{\circ} \mathrm{C}, 25^{\circ} \mathrm{C}, 30^{\circ} \mathrm{C}$, and $35^{\circ} \mathrm{C}$ but grew best at a temperature range of $25^{\circ} \mathrm{C}$ to $30^{\circ} \mathrm{C}$. Similarly, Ref [76] proved that $\mathrm{T}$. viride grew at temperatures ranging from $10^{\circ} \mathrm{C}$ to $30^{\circ} \mathrm{C}$, with maximum growth at $25^{\circ} \mathrm{C}$. In addition, $25^{\circ} \mathrm{C}$ was found to be the optimum incubation temperature for T. harzianum [6], while its 
highest antagonistic potential was at $20^{\circ} \mathrm{C}$ and the optimum range for the growth of T. harzianum and T. viride was $20-30{ }^{\circ} \mathrm{C}$ [77].

Table 3. The growth rate of Trichoderma strains on different media and at different incubation temperatures.

\begin{tabular}{ccccc}
\hline \multirow{2}{*}{ Trichoderma Strains } & \multicolumn{2}{c}{$25^{\circ} \mathbf{C}$} & \multicolumn{2}{c}{$35^{\circ} \mathbf{C}$} \\
\cline { 2 - 5 } & PDA & CMD & PDA & CMD \\
\hline$T a 1$ & $6.20 \pm 0.01$ & $4.75 \pm 0.10$ & $4.22 \pm 0.02$ & $2.60 \pm 0.41$ \\
\hline$T a 2$ & $5.84 \pm 0.06$ & $4.20 \pm 0.08$ & $3.20 \pm 0.47$ & $2.90 \pm 0.18$ \\
\hline$T h 3$ & $5.10 \pm 0.01$ & $5.10 \pm 0.29$ & $2.75 \pm 0.38$ & $3.50 \pm 0.38$ \\
\hline$T h 4$ & $5.33 \pm 0.09$ & $4.10 \pm 0.13$ & $2.50 \pm 0.31$ & $3.20 \pm 0.09$ \\
\hline$T l 5$ & $6.10 \pm 0.44$ & $4.90 \pm 0.50$ & $3.90 \pm 0.44$ & $2.75 \pm 0.46$ \\
\hline$T h 6$ & $6.00 \pm 0.47$ & $5.30 \pm 0.19$ & $4.30 \pm 0.13$ & $3.80 \pm 0.56$ \\
\hline$T h 7$ & $5.95 \pm 0.14$ & $5.25 \pm 0.14$ & $3.50 \pm 0.89$ & $3.00 \pm 0.67$ \\
\hline$T$ Tv & $5.00 \pm 0.45$ & $4.88 \pm 0.72$ & $2.70 \pm 0.57$ & $2.30 \pm 0.15$ \\
\hline
\end{tabular}

$\mathrm{CMD}=$ cornmeal dextrose agar; $\mathrm{PDA}=$ potato dextrose agar. Data are means \pm Standard error.

\subsubsection{Ability to Solubilize Insoluble Phosphate}

Solubilization of elements by biocontrol agents is achieved by chelation, reduction and hydrolysis. These mechanisms play a role in their effective biocontrol activity under various environmental conditions. The results were illustrated in Figures 3 and 4 and indicated that T. viride (Tv8) had the highest phosphate solubilization activity, followed by T. harzianum (Th4). On the other hand, T. harzianum (Th6) had the lowest phosphate solubilization ability. Our results proved that both $T$. asperellum strains (Ta1 and $\mathrm{Ta}$ ) had a higher phosphate solubilization index (6 and $8 \mathrm{~mm}$, respectively) as per a previous report [78] that T. asperellum $\mathrm{Q} 1$ was able to produce phosphatase enzymes for phosphate solubilization under salt stress conditions. Similar results were also recorded in another study [8], which found that T. asperelloides and T. harzianum were the highest phosphate solubilizers of five strains studied and suggested that Trichoderma strains used the solubilized phosphate in their cellular processes. These results were logical as it has been reported [79] that fungi have a large capability for solubilizing rock phosphate.

The variation of clear zones around the fungal growth shown in Figure 4 might be due to their ability to produce organic acids that can reduce $\mathrm{pH}$ and enhance the phosphates solubilisation as well as some of micro- and macro-nutrients [12,80,81]. Moreover, one study [1] reported that $T$. koningiopsis could solubilize phosphate under stress conditions such as alkalinity and drought by producing organic acids, accumulated polyphosphate in its mycelia, and produced alkaline phosphatase enzyme. One paper [82] suggested three possible mechanisms for phosphate solubilization by Trichoderma species-acidification of the microenvironment, production of chelating compounds, and redox activity- but, this paper denied the secretion of organic acids by Trichoderma strains, namely oxalic, citric, DL-malic, succinic, DL-lactic, and fumaric acids. However, another group [83] investigated these organic acids in two T. harzianum strains and their relationship with the promotion of tomato plant growth. Moreover, the recent study by Hewedy et al. [10], reported that the application of different Trichoderma strains significantly improved the growth parameters of pepper plants. A further study, [84] pointed out that phosphate can be solubilized in the absence of detectable chelating agents or organic acids but can be done by acidification of the medium. Finally, Trichoderma strains should have a higher stress tolerance than pathogens, qualifying them to carry out their work as biological control agents [85]. 


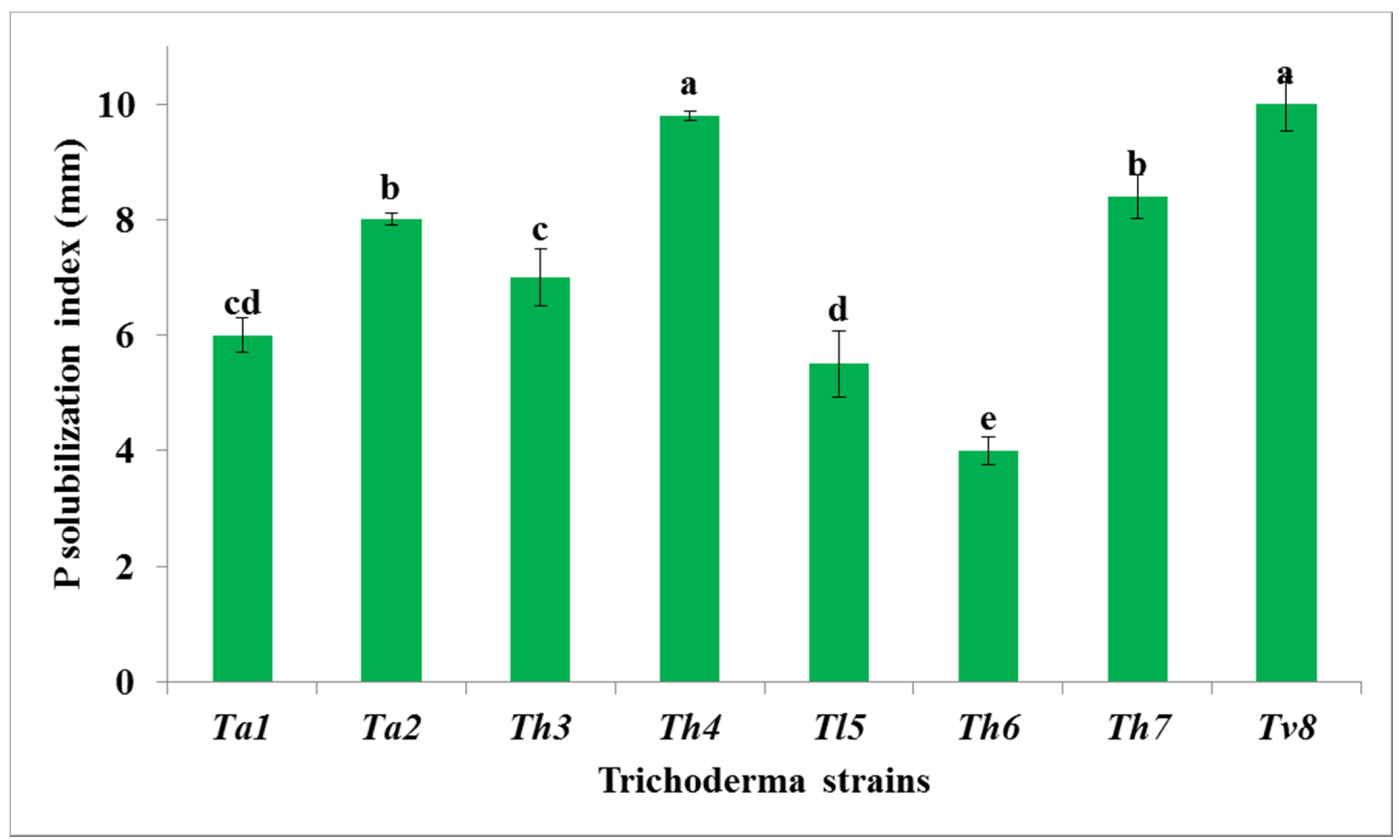

Figure 3. Growth of Trichoderma species on Modified Pikovskaya's Agar medium (MPA) supplemented with Rock Phosphate (RP) for phosphate -solubilization after seven days' incubation at $28 \pm 0.2{ }^{\circ} \mathrm{C} . \mathrm{Ta} 1=$ Trichoderma asperlum; Ta2 = Trichoderma asperlum; Th3 = Trichoderma harzianum; Th4 = Trichoderma harzianum; Tl5 = Trichoderma longibrachiatum; Th6 = Trichoderma harzianum; Th7 $=$ Trichoderma harzianum; $T$ 8 $8=$ Trichoderma viride.
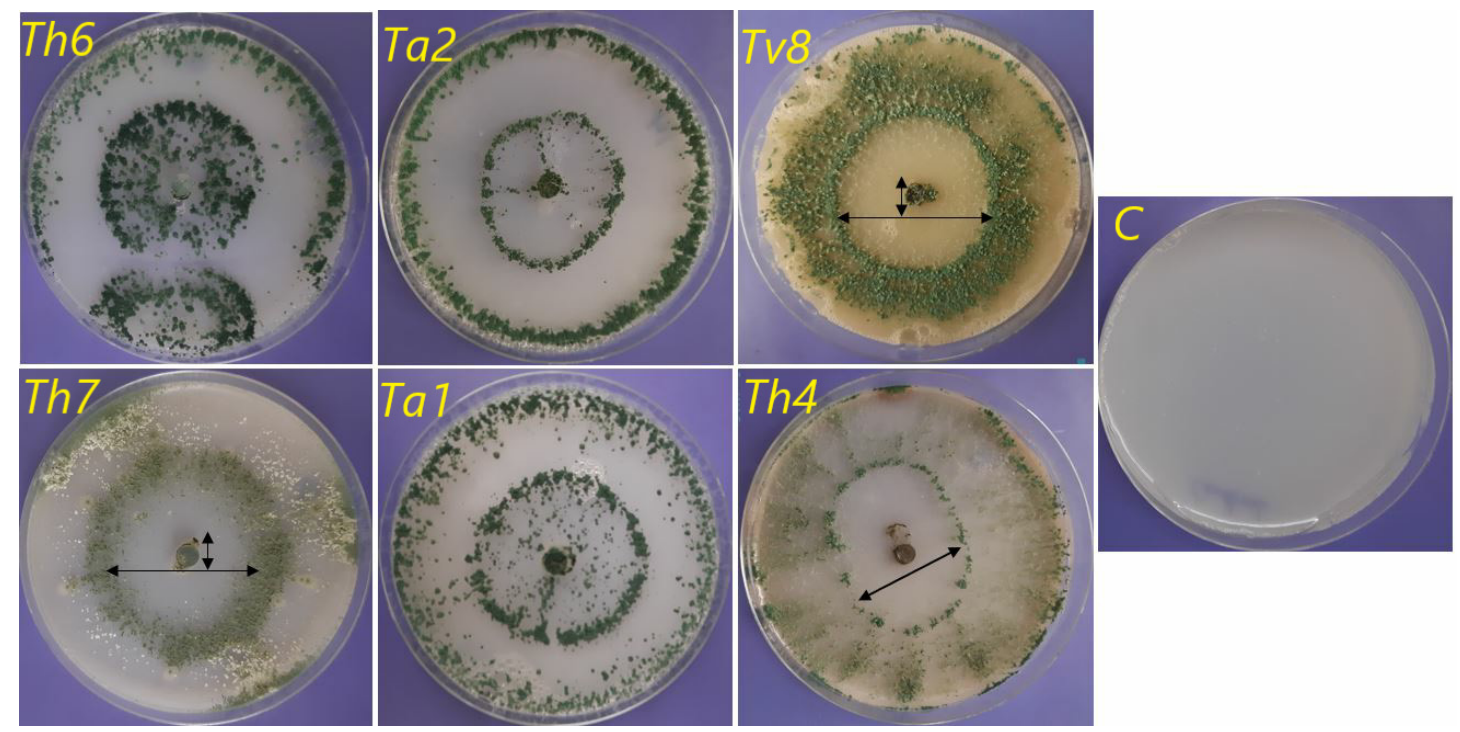

Figure 4. Growth of Trichoderma species on Modified Pikovskaya's Agar medium (MPA) supplemented with Rock Phosphate (RP) for phosphate -solubilization after seven days' incubation at $28 \pm 0.2{ }^{\circ} \mathrm{C}$.

\subsubsection{Ability to Antagonize Soil-Borne Pathogenic Fungi}

Plant pathogenic fungi cause harmful effects and the control of plant diseases by chemical pesticides represent a global problem. Moreover, the high cost linked with the only use of fungicides to reduce the development of plant disease, caused by soil-borne fungi, is not an effective approach. Thus, antifungal activity and the capability of various Egyptian Trichoderma strains to inhibit the growth of three soil-borne pathogens were tested in this work, as shown in (Table 4). The inhibition percentage of radial growth of $F$. solani in dual cultures was observed among Trichoderma strains, and T. harzianum (Th6; Figure 5) had the highest antagonistic activity. All Trichoderma strains consistently 
inhibited M. phaseolina as they grew superficially along with its colony and inhibited its growth by percentage ranged from $64.05 \%$ to $72.97 \%$ (Figure 6I,II). Extreme levels of inhibition were found in the F. graminearum-Trichoderma interactions, with inhibition percentage ranging from $69.23 \%$ to $84.61 \%$. These strains were recently tested against $F$. oxysporum $f$. sp. Capsici under greenhouse conditions, the results showed that the isolates Th7 and Th6 were the most effective Trichoderma strains in the suppression of Disease severity (DS) in plants foliage with $68.47 \%$ and $65.77 \%$ of reduction, respectively. Furthermore, this study revealed that Th7 was the most effective Trichoderma isolate in the suppression of DS in plants foliage (68.47\% of reduction) followed by Th6 $(65.77 \%$ of reduction) while the Th3 isolate was the lowest [10]. Inhibition of pathogens growth in the contact zone with Trichoderma spp. in dual cultures might be attributed to the production of inhibitory volatile and non-volatile compounds such as terpenes, pyrones, and polyketides [13], production of extracellular hydrolytic enzymes [7], and inactivation of the pathogen's enzymes [14].

Generally, the data indicated that T. harzianum (Th6, Figure 5) caused the highest inhibitor for all pathogenic strains. F. graminearum was the weakest pathogenic strain, showing inhibition of $84.61 \%$ by Th6. In contrast, T. viride (Tv8) had the lowest inhibition percent for all pathogenic strains. Similar results were previously recorded by [15] in a study which tested T. harzianum against three pathogenic fungi (Phyllosticta sphaeropsoidea, Phomopsis carposchiza, and Diaporthe padi) and found an inhibition percentage of up to $20 \%$. Other previous work [86], tested two Trichoderma strains against 18 Botrytis cinerea strains and found that the mycelial growth inhibition from $74.2 \%$ to $96.9 \%$ and from $71.1 \%$ to 95.9\% for T. asperellum and T. harzianum, respectively. The most inhibited pathogenic fungus as a result of Trichoderma strains was the F. graminearum compared with the other two pathogenic fungi (Table 4).

Table 4. Antagonistic activity of Trichoderma strains against three pathogenic fungi by dual culture technique.

\begin{tabular}{ccccccc}
\hline \multirow{2}{*}{ Trichoderma Strains } & \multicolumn{2}{c}{ F. solani } & \multicolumn{2}{c}{ M. phaseolina } & \multicolumn{2}{c}{ F. graminearum } \\
\cline { 2 - 6 } & RMG (cm) & IMG (\%) & RMG (cm) & IMG (\%) & RMG (cm) & IMG (\%) \\
\hline Control & $3.50 \pm 0.06$ & 0.00 & $3.70 \pm 0.30$ & 0.00 & $6.50 \pm 0.16$ & 0.00 \\
Ta1 & $1.40 \pm 0.09$ & 60.00 & $1.20 \pm 0.31$ & 67.56 & $1.50 \pm 0.08$ & 76.92 \\
Ta2 & $1.65 \pm 0.06$ & 52.85 & $1.10 \pm 0.10$ & 70.27 & $1.20 \pm 0.21$ & 81.53 \\
Th3 & $1.55 \pm 0.15$ & 55.71 & $1.30 \pm 0.22$ & 64.86 & $1.50 \pm 0.17$ & 76.92 \\
Th4 & $1.75 \pm 0.38$ & 50.01 & $1.14 \pm 0.07$ & 69.18 & $1.80 \pm 0.49$ & 72.30 \\
Tl5 & $1.70 \pm 0.32$ & 51.42 & $1.01 \pm 0.11$ & 72.96 & $1.20 \pm 0.01$ & 81.53 \\
Th6 & $1.00 \pm 0.01$ & 71.42 & $1.00 \pm 0.13$ & 72.97 & $1.00 \pm 0.15$ & 84.61 \\
Th7 & $1.55 \pm 0.40$ & 55.71 & $1.20 \pm 0.20$ & 67.56 & $1.01 \pm 0.01$ & 84.60 \\
Tv8 & $1.75 \pm 0.30$ & 50.00 & $1.33 \pm 0.08$ & 64.05 & $2.00 \pm 0.32$ & 69.23 \\
\hline
\end{tabular}

RMG: Radial Mycelial growth; IMG: Inhibition of mycelial growth. Data are means \pm Standard error.
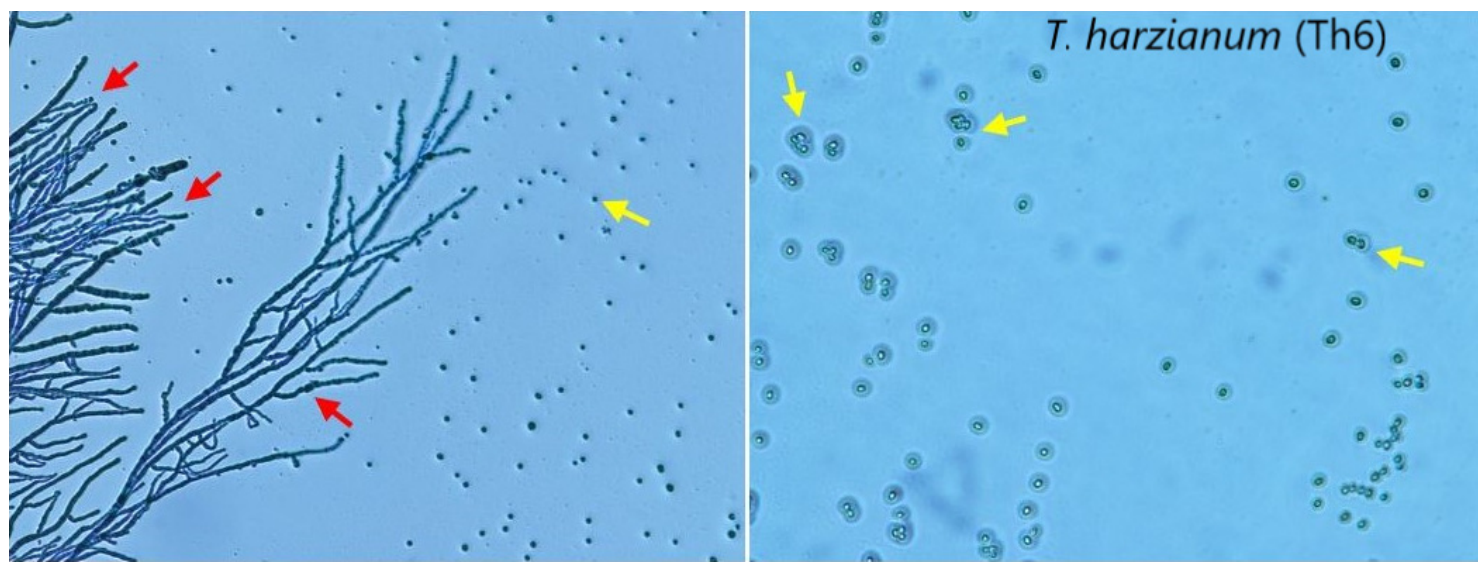

Figure 5. The conidiophores (red arrows) and conidia (yellow arrows) of the Th6 strain. 
(I)

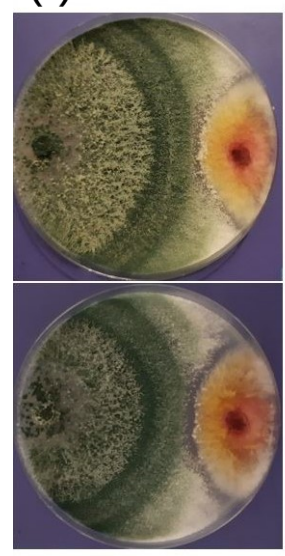

(II)

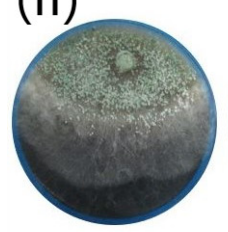

(III)
(IV)
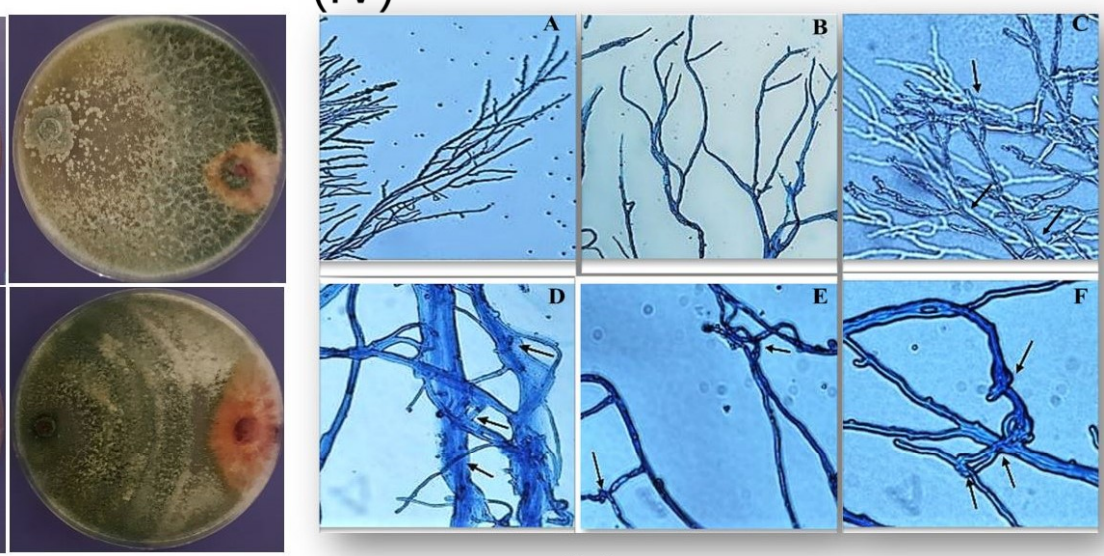

$(\mathrm{V})$
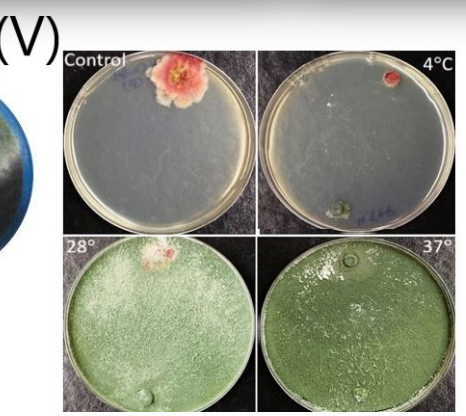

Figure 6. (I) In vitro dual culture assay of different Trichoderma strains against $F$. graminearum; (II) In vitro dual culture assay of different Trichoderma strains against Macrophomina phaseolina; (III) Detection of $\beta$-1,3-endoglucanase gene for eight Trichoderma strains; (IV) Examination of the confrontation activity of Th6 strain and Fg using light microscopy: (A) T. harzianum (Th6) as control without pathogen; (B) F. graminearum $(F g)$ as control without Trichoderma; (C-F) the interaction between $T h 6$ and $F g$ at a different time: (C) $10 \mathrm{~min}$; (D) $20 \mathrm{~min}$; (E) $30 \mathrm{~min}$ and (F) $60 \mathrm{~min}$. The arrows mean the mycoparasitism processes involving the hyphal interactions by the attachment and coiling (dark blue) in the panel D and E before killing the pathogen in panel F. (V) Growth inhibition of pathogenic fungus $(\mathrm{Fg})$ mycelia in vitro dual culture with $T h 6$ at different temperatures $\left(4^{\circ} \mathrm{C}, 28{ }^{\circ} \mathrm{C}\right.$ and $\left.37^{\circ} \mathrm{C}\right)$.

\subsubsection{Rate and Speed of Growth}

The faster growth rates among the studied Trichoderma strains compared with F. graminearum was considered one of the most common antagonistic mechanisms as a way of competing for space and nutrients. As shown in Figure S1, F. graminearum was the pathogen with the slowest growth rate compared to all Trichoderma strains. This means that Trichoderma used its ability for faster growth as an essential mechanism to compete with pathogenic fungi. Moreover, rapid growth rate helps Trichoderma strains to compete with pathogens by solubilizing phosphate faster to facilitate their mycelial growth [8]. In comparison, most plant pathogenic fungi are incapable of solubilizing phosphate. They can easily be attacked by the highly efficient phosphate solubilizing T. harzianum. Several studies $[20,82]$ reported that high temperature could induce T. asperellum mycelia to form a massive number of conidia in a short time and speed up the spread of conidia, forming a sizeable infected area with Trichoderma.

\subsection{T. harzianum (Th6) against F. graminearum}

\subsubsection{Mycoparasitic Activity at Different Temperatures}

Different Trichoderma species can live in various climatic environments that determine their distributions [20]. In this experiment, the strain with the strongest inhibitory activity T. harzianum (Th6, Figure 5) was selected to inhibit $F$. graminearum at a wide range of temperatures $\left(4^{\circ} \mathrm{C}, 28^{\circ} \mathrm{C}\right.$, and $37^{\circ} \mathrm{C}$ ), and the data are illustrated in Table S1 and (Figure 6V). The data in Table S1 indicate that 
F. graminearum grow slow rate at $4{ }^{\circ} \mathrm{C}$ than at other temperatures. Although the optimum temperature for $F$. graminearum was $25^{\circ} \mathrm{C}$, its growth rate was faster at $37^{\circ} \mathrm{C}$ than $28^{\circ} \mathrm{C}$.

The highest inhibition rate of $F$. graminearum mycelial growth $(76.9 \%)$ was recorded after $120 \mathrm{~h}$ at $37^{\circ} \mathrm{C}$, while the lowest inhibition $(18 \%)$ was recorded after $72 \mathrm{~h}$ at $28^{\circ} \mathrm{C}$. At $28^{\circ} \mathrm{C}$ and $37^{\circ} \mathrm{C}$ the inhibition rates gradually increased after $72 \mathrm{~h}$ of growth and reached their maximum after $120 \mathrm{~h}$. On the other hand, the inhibition rate of $F$. graminearum at $4{ }^{\circ} \mathrm{C}$ decreased after $72 \mathrm{~h}$ and then remained constant. At $4{ }^{\circ} \mathrm{C}$, despite there is no mycelial contact between the two tested fungi, F. graminearum was inhibited (Figure 6 and Table S1), the reason might be related to the diffusion of secondary metabolites in the medium.

An earlier [20] clarified the effect of temperature on Trichoderma antagonistic activity, showing that Trichoderma species attach to the pathogenic fungal cell by secretion of cell wall carbohydrates which bind to the pathogenic fungi's lectins. The lectin content of pathogenic fungi was increased at high temperature (around $36^{\circ} \mathrm{C}$ ), causing pathogenic fungi mycelia to adsorb more conidia and be infected by T. asperellum. Moreover, another study [87] demonstrated that Trichoderma conidia could accumulate intracellular sugars for instance mannitol and trehalose under thermal stress. These sugars could enhance both germination and conidial bioactivity as well as the tolerance of stressful conditions.

\subsubsection{Light Microscopic Examination}

Microscopic examination of the antagonist (T. harzianum "Th6") and pathogen (F. graminearum) mycelia and the interactions between them is showing in (Figure 6IV (C-F)). In this experiment, PDA plates were inoculated with two mycelial disks cut from one Trichoderma strain and one pathogen. The fungal strains grew toward each other, and their hyphae interacted. After $48 \mathrm{~h}$ of incubation at $25^{\circ} \mathrm{C}$, contact between the two fungi with parallel growth of T. harzianum (Th6) alongside F. graminearum hypha was spotted, then coiling of the antagonists around the pathogen were observed after $20 \mathrm{~min}$ (Figure 6IV(D)). Formation of appressorium-like structures and suffocation were observed after 30 and $60 \mathrm{~min}$ of contact (Figure 6IV(E,F)). Moreover, suffocation of F. graminearum mycelium was observed at contact sites with T. harzianum. Similar results recorded mycoparasitism (penetration, coiling and parallel growth) of T. harzianum against two Colletotrichum species [88], Sclerotium rolfsii [89] and Sclerotinia sclerotiorum [90].

\section{Conclusions}

Trichoderma strains could inhibit three soil-borne pathogens in vitro hyperparasitic activity. The antigenicity of endophytic fungi is not only related to the number of different species in the rhizosphere but also the diversity relationship between the different Trichoderma strains. This investigation showed the effectiveness of RAPD and SSR markers in ascertaining the genetic relationships among eight Trichoderma species. The RAPD markers proved to be less precise while the SSR markers showed the highest efficacy among the strains. The results of phosphate solubilization investigation imply that Trichoderma species have the ability to solubilize insoluble phosphate for enhancing the phosphate uptake by plants in fields. T. viride (Tv8) had the highest phosphate solubilization index $(10.0 \mathrm{~mm})$ compared with the other strains.

Additionally, T. harzianum (Th6) had the highest antagonistic activity in dual culture assay along with the growth rate. Based on our experimental approach, the T. harzianum (Th6) strain seems to present interesting features as a potential biocontrol agent. However, further studies are needed in order to determine whether the combination of the biological control and biofertilization using this strain will provide a benefit to more efficient and safer formulations to the environment and the producers. Furthermore, the analysis of secreted enzymes and secondary metabolites related to the control of the phytopathogens along with the type of plant response to this strain, would provide a better understanding between the antagonistic efficiency of Trichoderma strains and their diversity. In sum, this approach for the activity of microbe-microbe interactions and the multiple mechanisms of the biological agents will open up new avenues in plant beneficial microbes. 
Supplementary Materials: The following are available online at http://www.mdpi.com/2079-7737/9/8/189/s1, Figure S1: Competition of fungal pathogen F.g and Trichoderma strains, Table S1: Antagonistic activity of T. harzianum (Th6) against F. graminearum under thermal stress.

Author Contributions: Conceptualization: O.A.H., K.S.A.L., M.F.S., A.S., F.M.A. and R.M.E.-M. Data curation: O.A.H., K.S.A.L., F.M.A. and A.S. Formal analysis: O.A.H., K.S.A.L., M.F.S., A.S., F.M.A. and R.M.E.-M., Investigation: O.A.H., K.S.A.L., M.F.S., A.S., F.M.A. and R.M.E.-M. Methodology: O.A.H., K.S.A.L. and R.M.E.-M. Resources: O.A.H. and R.M.E.-M. Software: O.A.H., K.S.A.L., A.S., F.M.A. and R.M.E.-M. Writing-original draft: O.A.H., K.S.A.L., A.S., F.M.A., M.F.S. and R.M.E.-M. Writing-review and editing: O.A.H. and M.F.S. All authors have read and agreed to the published version of the manuscript.

Funding: This research received no external funding.

Acknowledgments: The Deanship of Scientific Research and RSSU at King Saud University are acknowledged. Omar Hewedy was supported by a generous scholarship from the Government of Egypt. He would like to thank the Ministry of Higher Education - Cultural Affairs \& Missions Sector in Egypt for their support.

Conflicts of Interest: The authors declare no conflict of interest.

\section{References}

1. Tandon, A.; Fatima, T.; Shukla, D.; Tripathi, P.; Srivastava, S.; Singh, P.C. Phosphate solubilization by Trichoderma koningiopsis (NBRI-PR5) under abiotic stress conditions. J. King Saud Univ. Sci. 2020, 32, 791-798. [CrossRef]

2. Caon, L.; Vargas, R. Threats to Soils: Global trends and Perspectives; Working Paper; United Nations: New York, NY, USA, 2017.

3. Yedidia, I.; Srivastva, A.K.; Kapulnik, Y.; Chet, I. Effect of Trichoderma harzianum on microelement concentrations and increased growth of cucumber plants. Plant Soil 2001, 235, 235-242. [CrossRef]

4. Druzhinina, I.S.; Seidl-Seiboth, V.; Herrera-Estrella, A.; Horwitz, B.A.; Kenerley, C.M.; Monte, E.; Mukherjee, P.K.; Zeilinger, S.; Grigoriev, I.V.; Kubicek, C.P. Trichoderma: The genomics of opportunistic success. Nat. Rev. Microbiol. 2011, 9, 749-759. [CrossRef]

5. Harman, G.E.; Howell, C.R.; Viterbo, A.; Chet, I.; Lorito, M. Trichoderma species-Opportunistic, avirulent plant symbionts. Nat. Rev. Microbiol. 2004, 2, 43-56. [CrossRef] [PubMed]

6. Sinha, A.; Harshita, D.; Singh, R.; Rao, S.G.; Verma, A. Comprehensive evaluation of Trichoderma harzianum and Trichoderma viride on different culture media \& at different temperature and pH. Pharma Innov. J. 2018, 7, 193-195.

7. Zehra, A.; Dubey, M.; Meena, M.; Upadhyay, R. Effect of different environmental conditions on growth and sporulation of some Trichoderma species. J. Environ. Biol. 2017, 38, 197. [CrossRef]

8. Borges Chagas, L.; Chagas Junior, A.; Rodrigues de Carvalho, M.; de Oliveira Miller, L.; Colonia, O. Evaluation of the phosphate solubilization potential of Trichoderma strains (Trichoplus JCO) and effects on rice biomass. J. Soil Sci. Plant Nutr. 2015, 15, 794-804. [CrossRef]

9. Rawat, R.; Tewari, L. Effect of abiotic stress on phosphate solubilization by biocontrol fungus Trichoderma sp. Curr. Microbiol. 2011, 62, 1521-1526. [CrossRef]

10. Hewedy, O.A.; Abdel-Lateif, K.S.; Bakr, R.A. Genetic diversity and biocontrol efficacy of indigenous Trichoderma isolates against Fusarium wilt of pepper. J. Basic Microbiol. 2020, 60, 126-135. [CrossRef]

11. López-Mondéjar, R.; Ros, M.; Pascual, J.A. Mycoparasitism-related genes expression of Trichoderma harzianum isolates to evaluate their efficacy as biological control agent. Biol. Control 2011, 56, 59-66. [CrossRef]

12. Alori, E.T.; Glick, B.R.; Babalola, O.O. Microbial phosphorus solubilization and its potential for use in sustainable agriculture. Front. Microbiol. 2017, 8, 971. [CrossRef] [PubMed]

13. Rao, G.S.; Reddy, N.N.R.; Surekha, C. Induction of plant systemic resistance in Legumes cajanus cajan, Vigna radiata, Vigna mungo against plant pathogens Fusarium oxysporum and alternaria alternata-a Trichoderma viride mediated reprogramming of plant defense mechanism. Int. J. Recent Sci. Res 2015, 6, 4270-4280.

14. Maurya, M.K.; Srivastava, M.; Singh, A.; Pandey, S.; Ratan, V. Effect of different temperature and culture media on the mycelia growth of Trichoderma viride isolates. Int. J. Curr. Microbiol. Appl. Sci 2017, 60, 266-269. [CrossRef]

15. Pastirčáková, K. In vitro interactions between Trichoderma harzianum and pathogenic fungi damaging horse-chestnut (Aesculus hippocastanum) leaves and fruits. Biol. Lett. 2019, 54, 21-35. [CrossRef] 
16. Dłużniewska, J. Reaction of Fungi of Trichoderma Genus to Selected Abiotic Factors. Available online: http://www.ejpau.media.pl/volume6/issue2/agronomy/art-04.Html (accessed on 21 July 2020).

17. Narsian, V.; Patel, H. Aspergillus aculeatus as a rock phosphate solubilizer. Soil Biol. Biochem. 2000, 32, 559-565. [CrossRef]

18. Singh, A.; Shahid, M.; Srivastava, M.; Pandey, S.; Sharma, A.; Kumar, V. Optimal physical parameters for growth of Trichoderma species at varying pH, temperature and agitation. Virol. Mycol. 2014, 3, 127-134.

19. Domingues, M.V.P.F.; Moura, K.E.d.; Salomão, D.; Elias, L.M.; Patricio, F.R.A. Effect of temperature on mycelial growth of Trichoderma, Sclerotinia minor and S. sclerotiorum, as well as on mycoparasitism. Summa Phytopathol. 2016, 42, 222-227. [CrossRef]

20. Qiu, Z.; Wu, X.; Zhang, J.; Huang, C. High temperature enhances the ability of Trichoderma asperellum to infect Pleurotus ostreatus mycelia. PLoS ONE 2017, 12, e0187055. [CrossRef]

21. Rojo, F.G.; Reynoso, M.M.; Ferez, M.; Chulze, S.N.; Torres, A.M. Biological control by Trichoderma species of Fusarium solani causing peanut brown root rot under field conditions. Crop Prot. 2007, 26, 549-555. [CrossRef]

22. Saravanakumar, K.; Li, Y.; Yu, C.; Wang, Q.Q.; Wang, M.; Sun, J.; Gao, J.X.; Chen, J. Effect of Trichoderma harzianum on maize rhizosphere microbiome and biocontrol of Fusarium Stalk rot. Sci. Rep. 2017, 7, 1-13.

23. Aly, A.A.; Abdel-Sattar, M.A.; Omar, M.R.; Abd-Elsalam, K.A. Differential antagonism of Trichoderma sp. against Macrophomina phaseolina. J. Plant Prot. Res. 2007, 47, 91-102.

24. Samuels, G.J.; Dodd, S.L.; Gams, W.; Castlebury, L.A.; Petrini, O. Trichoderma species associated with the green mold epidemic of commercially grown Agaricus bisporus. Mycologia 2002, 94, 146-170. [CrossRef] [PubMed]

25. Kamala, T.; Devi, S.I.; Sharma, K.C.; Kennedy, K. Phylogeny and taxonomical investigation of Trichoderma spp. from Indian region of Indo-Burma biodiversity hot spot region with special reference to Manipur. BioMed Res. Int. 2015, 2015, 285261. [CrossRef] [PubMed]

26. Lind, A.L.; Wisecaver, J.H.; Lameiras, C.; Wiemann, P.; Palmer, J.M.; Keller, N.P.; Rodrigues, F.; Goldman, G.H.; Rokas, A. Drivers of genetic diversity in secondary metabolic gene clusters in a fungal population. bioRxiv 2017, 149856. [CrossRef]

27. Chaverri, P.; Branco-Rocha, F.; Jaklitsch, W.; Gazis, R.; Degenkolb, T.; Samuels, G.J. Systematics of the Trichoderma harzianum species complex and the re-identification of commercial biocontrol strains. Mycologia 2015, 107, 558-590. [CrossRef]

28. Komoń-Zelazowska, M.; Bissett, J.; Zafari, D.; Hatvani, L.; Manczinger, L.; Woo, S.; Lorito, M.; Kredics, L.; Kubicek, C.P.; Druzhinina, I.S. Genetically closely related but phenotypically divergent Trichoderma species cause green mold disease in oyster mushroom farms worldwide. Appl. Environ. Microbiol. 2007, 73, 7415-7426. [CrossRef]

29. Atanasova, L.; Druzhinina, I.S.; Jaklitsch, W.M.; Mukherjee, P.; Horwitz, B.; Singh, U. Two hundred Trichoderma species recognized on the basis of molecular phylogeny. In Trichoderma: Biology and Applications; Cabi: Wallingford, UK, 2013; pp. 10-42.

30. Geiser, D.M.; del Mar Jiménez-Gasco, M.; Kang, S.; Makalowska, I.; Veeraraghavan, N.; Ward, T.J.; Zhang, N.; Kuldau, G.A.; O'donnell, K. FUSARIUM-ID v. 1.0: A DNA sequence database for identifying Fusarium. Eur. J. Plant Pathol. 2004, 110, 473-479. [CrossRef]

31. Oskiera, M.; Szczech, M.; Bartoszewski, G. Molecular identification of Trichoderma strains collected to develop plant growth-promoting and biocontrol agents. J. Hortic. Res. 2015, 23, 75-86. [CrossRef]

32. Saravanakumar, K.; Yu, C.; Dou, K.; Wang, M.; Li, Y.; Chen, J. Biodiversity of Trichoderma community in the tidal flats and wetland of southeastern China. PLoS ONE 2016, 11, e0168020. [CrossRef]

33. Haddad, P.E.; Leite, L.G.; Lucon, C.M.M.; Harakava, R. Selection of Trichoderma spp. strains for the control of Sclerotinia sclerotiorum in soybean. Pesqui. Agropecuária Bras. 2017, 52, 1140-1148. [CrossRef]

34. Hussein, M.H.; Abdel-Hamid, A.; Hussein, B.A.; Nasseef, M.; El-Morshedyand, J. The Suitability of RAPD Markers in Identifying Some Hexaploid Wheat Crosses. World Appl. Sci. J. 2013, 21, 732-738.

35. Shahid, M.; Srivastava, M.; Kumar, V.; Singh, A.; Sharma, A.; Pandey, S.; Rastogi, S.; Pathak, N.; Srivastava, A. Phylogenetic diversity analysis of Trichoderma species based on internal transcribed spacer (ITS) marker. Afr. J. Biotechnol. 2014, 13. [CrossRef]

36. Hadrys, H.; Balick, M.; Schierwater, B. Applications of random amplified polymorphic DNA (RAPD) in molecular ecology. Mol. Ecol. 1992, 1, 55-63. [CrossRef] [PubMed] 
37. Gupta, V.; Misra, A.; Gupta, A.; Pandey, B.; Gaur, R. Rapd-Pcr of Trichoderma Isolates and In Vitro Antagonism Against Fusarium Wilt Pathogens of Psidium Guajaval. J. Plant Prot. Res. 2010, 50, 256. [CrossRef]

38. Chakraborty, B.; Chakraborty, U.; Sunar, K.; Dey, P. RAPD profile and rDNA sequence analysis of Talaromyces flavus and Trichoderma species. NISCAIR-CSIR 2011, 11, 487-495.

39. El_Komy, M.H.; Saleh, A.A.; Eranthodi, A.; Molan, Y.Y. Characterization of novel Trichoderma asperellum isolates to select effective biocontrol agents against tomato Fusarium wilt. Plant Pathol. J. 2015, 31, 50. [CrossRef]

40. Pandya, J.; Sabalpara, A.; Mahatma, M. Randomly amplified polymorphic DNA analysis of native Trichoderma isolates. Asian J. Appl. Sci. Technol. 2017, 1, 147-150.

41. Khattak, B.; Saifullah, S.H.; Ahmad, M.; Ali, A.; Junaid, M.; Khan, I.A.; Khan, T.A.; Hussain, M. Genetic Relatedness among the Indigenous Isolates of Trichoderma harzianum, using RAPD and their Nematocidal Capabilities against Meloidogyne javanica. J. Agric. 2018, 34, 486-493. [CrossRef]

42. Shahid, M.; Srivastava, M.; Sharma, A.; Kumar, V.; Pandey, S.; Singh, A. Morphological, molecular identification and SSR marker analysis of a potential strain of Trichoderma/Hypocrea for production of a bioformulation. J. Plant Pathol. Microbiol. 2013, 4, 1. [CrossRef]

43. Mahfooz, S.; Singh, S.P.; Rakh, R.; Bhattacharya, A.; Mishra, N.; Singh, P.C.; Chauhan, P.S.; Nautiyal, C.S.; Mishra, A. A comprehensive characterization of simple sequence repeats in the sequenced Trichoderma genomes provides valuable resources for marker development. Front. Microbiol. 2016, 7, 575. [CrossRef]

44. Geistlinger, J.; Zwanzig, J.; Heckendorff, S.; Schellenberg, I. SSR markers for Trichoderma virens: Their evaluation and application to identify and quantify root-endophytic strains. Diversity 2015, 7, 360-384. [CrossRef]

45. Kretsinger, R.H.; Wasserman, R.H. Structure and evolution of calcium-modulated protein. Crit. Rev. Biochem. 1980, 8, 119-174. [CrossRef] [PubMed]

46. Gadd, G. Signal transduction in fungi. In The Growing Fungus; Springer: Berlin/Heidelberg, Germany, 1995; pp. 183-210.

47. Muthukumar, G.; Nickerson, K.W. Ca (II)-calmodulin regulation of fungal dimorphism in Ceratocystis ulmi. J. Bacteriol. 1984, 159, 390-392. [CrossRef] [PubMed]

48. Carbone, I.; Kohn, L.M. A method for designing primer sets for speciation studies in filamentous ascomycetes. Mycologia 1999, 91, 553-556. [CrossRef]

49. Montoya, Q.V.; Meirelles, L.A.; Chaverri, P.; Rodrigues, A. Unraveling Trichoderma species in the attine ant environment: Description of three new taxa. Antonie van Leeuwenhoek 2016, 109, 633-651. [CrossRef]

50. Druzhinina, I.S.; Kopchinskiy, A.G.; Komoń, M.; Bissett, J.; Szakacs, G.; Kubicek, C.P. An oligonucleotide barcode for species identification in Trichoderma and Hypocrea. Fungal Genet. Biol. 2005, 42, 813-828. [CrossRef]

51. Dodd, S.L.; Lieckfeldt, E.; Chaverri, P.; Overton, B.E.; Samuels, G.J. Taxonomy and phylogenetic relationships of two species of Hypocrea with Trichoderma anamorphs. Mycol. Prog. 2002, 1, 409-428. [CrossRef]

52. Williams, J.G.; Kubelik, A.R.; Livak, K.J.; Rafalski, J.A.; Tingey, S.V. DNA polymorphisms amplified by arbitrary primers are useful as genetic markers. Nucleic Acids Res. 1990, 18, 6531-6535. [CrossRef]

53. Samuels, G.J.; Suarez, C.; Solis, K.; Holmes, K.A.; Thomas, S.E.; Ismaiel, A.; Evans, H.C. Trichoderma theobromicola and T. paucisporum: Two new species isolated from cacao in South America. Mycol. Res. 2006, 110, 381-392. [CrossRef]

54. Vieira, P.M.; Coelho, A.S.G.; Steindorff, A.S.; de Siqueira, S.J.L.; do Nascimento Silva, R.; Ulhoa, C.J. Identification of differentially expressed genes from Trichoderma harzianum during growth on cell wall of Fusarium solanias a tool for biotechnological application. BMC Genom. 2013, 14, 177. [CrossRef]

55. Jaklitsch, W.M.; Komon, M.; Kubicek, C.P.; Druzhinina, I.S. Hypocrea voglmayrii sp. nov. from the Austrian Alps represents a new phylogenetic clade in Hypocrea/Trichoderma. Mycologia 2005, 97, 1365-1378. [CrossRef] [PubMed]

56. Nautiyal, C.S. An efficient microbiological growth medium for screening phosphate solubilizing microorganisms. FEMS Microbiol. Lett. 1999, 170, 265-270. [CrossRef]

57. Afzal, A.; Bano, A. Rhizobium and phosphate solubilizing bacteria improve the yield and phosphorus uptake in wheat (Triticum aestivum). Int. J. Agric. Biol. 2008, 10, 85-88.

58. Morton, D.; Stroube, W. Antagonistic and stimulatory effects of soil microorganisms upon Sclerotium rolfsii. Phytopathology 1955, 45, 417-420. 
59. Edgington, L.; Khew, K.; Barron, G. Fungitoxic spectrum of benzimidazole compounds. Phytopathology 1971, 61, 42-44. [CrossRef]

60. Hajieghrari, B.; Torabi-Giglou, M.; Mohammadi, M.R.; Davari, M. Biological potantial of some Iranian Trichoderma isolates in the control of soil borne plant pathogenic fungi. Afr. J. Biotechnol. 2008, 967-972.

61. Mousa, W.K.; Shearer, C.R.; Limay-Rios, V.; Zhou, T.; Raizada, M.N. Bacterial endophytes from wild maize suppress Fusarium graminearum in modern maize and inhibit mycotoxin accumulation. Front. Plant Sci. 2015, 6, 805. [CrossRef]

62. Jamshidi, S.; Jamshidi, S. NTSYSpc 2.02 e implementation in molecular biodata analysis (clustering, screening, and individual selection). In Proceedings of the 4th International Conference on Environmental and Computer Science, Singapore, 28-29 October 2017; pp. 16-18.

63. Alhawatema, M.; Al Tawaha, A.A.A.R. Application of Using DNA Barcoding Genes in Identification of Fungi Species, a Review. Biosci. Res. 2019, 16, 1763-1775.

64. De La Cruz, J.; Pintor-Toro, J.A.; Benitez, T.; Llobell, A.; Romero, L.C. A novel endo-beta-1, 3-glucanase, BGN13. 1, involved in the mycoparasitism of Trichoderma harzianum. J. Bacteriol. 1995, 177, 6937-6945. [CrossRef]

65. Harman, G.E. Myths and dogmas of biocontrol changes in perceptions derived from research on Trichoderma harzinum T-22. Plant Dis. 2000, 84, 377-393. [CrossRef]

66. Sharma, P.; Kumar, V.; Ramesh, R.; Saravanan, K.; Deep, S.; Sharma, M.; Mahesh, S.; Dinesh, S. Biocontrol genes from Trichoderma species: A review. Afr. J. Biotechnol. 2011, 10, 19898-19907.

67. Chen, L.; Zou, G.; Wang, J.; Wang, J.; Liu, R.; Jiang, Y.; Zhao, G.; Zhou, Z. Characterization of the $\mathrm{Ca} 2+-$ responsive signaling pathway in regulating the expression and secretion of cellulases in Trichoderma reesei Rut-C30. Mol. Microbiol. 2016, 100, 560-575. [CrossRef] [PubMed]

68. Xiong, F.; Zhong, R.; Han, Z.; Jiang, J.; He, L.; Zhuang, W.; Tang, R. Start codon targeted polymorphism for evaluation of functional genetic variation and relationships in cultivated peanut (Arachishypogaea, L.) genotypes. Mol. Biol. Rep. 2011, 38, 3487-3494. [CrossRef] [PubMed]

69. Singh, U.; Joshi, D.; Zaidi, N. Biodiversity in biocontrol agent, Trichoderma spp.: Characterization and util. ization. J. Mycol. Plant Pathol. 2006, 36, 461-463.

70. Choudary, K.; Reddy, K.; Reddy, M. Antifungal activity and genetic variability of Trichoderma harzianum isolates. J. Mycol. Plant Pathol. 2007, 37, 1-6.

71. Limón, M.; Chacón, M.; Mejías, R.; Delgado-Jarana, J.; Rincón, A.; Codón, A.; Benítez, T. Increased antifungal and chitinase specific activities of Trichoderma harzianum CECT 2413 by addition of a cellulose binding domain. Appl. Microbiol. Biotechnol. 2004, 64, 675-685. [CrossRef]

72. Azher, M.; Khan, M.A.; Inam-ul-Haq, M.; Khan, S.; Pervez, M.A. Mass multiplication of Trichoderma spp. on organic substrate and their effect in management of seed borne fungi. Pak. J. Phytopathol. 2009, 21, 108-114.

73. Jahan, N.; Sultana, S.; Adhikary, S.; Rahman, S.; Yasmin, S. Evaluation of the growth performance of Trichoderma harzianum (Rifai.) on different culture media. J. Agri. Vet. Sci. 2013, 3, 44-50. [CrossRef]

74. Mustafa, A.; Khan, M.A.; Inam-ul-Haq, M.; Pervez, M.A.; Umar, U. Usefulness of different culture media for in vitro evaluation of Trichoderma spp. against seed borne fungi of economic importance. Pak. J. Phytopathol. 2009, 21, 83-88.

75. Santamarina, M.P.; Rosello, J. Influence of temperature and water activity on the antagonism of Trichoderma harzianum to Verticillium and Rhizoctonia. Crop Prot. 2006, 25, 1130-1134. [CrossRef]

76. Jackson, A.; Whipps, J.; Lynch, J. Effects of temperature, $\mathrm{pH}$ and water potential on growth of four fungi with disease biocontrol potential. World J. Microbiol. Biotechnol. 1991, 7, 494-501. [CrossRef] [PubMed]

77. Ali, M.; Yasser, M.; Mousa, A.; Khalek, M.A. Optimization of factors affecting proliferation and flourishment of Trichoderma harzianum in Egyptian soil. J. Basic Appl. Mycol. 2012, 3, 41-48.

78. Lei, Z.; Qun, L.; Zhang, Y.Q.; Cui, Q.Y.; Liang, Y.C. Effect of acid phosphatase produced by Trichoderma asperellum Q1 on growth of Arabidopsis under salt stress. J. Integr. Agric. 2017, 16, 1341-1346.

79. Saxena, J.; Chandra, S.; Nain, L. Synergistic effect of phosphate solubilizing rhizobacteria and arbuscular mycorrhiza on growth and yield of wheat plants. J. Soil Sci. Plant Nutr. 2013, 13, 511-525.

80. Promwee, A.; Issarakraisila, M.; Intana, W.; Chamswarng, C.; Yenjit, P. Phosphate solubilization and growth promotion of rubber tree (Hevea brasiliensis Muell. Arg.) by Trichoderma strains. J. Agric. Sci. 2014, 6, 8. [CrossRef] 
81. Gaind, S. Phosphate dissolving fungi: Mechanism and application in alleviation of salt stress in wheat. Microbiol. Res. 2016, 193, 94-102. [CrossRef]

82. Altomare, C.; Norvell, W.; Björkman, T.; Harman, G. Solubilization of phosphates and micronutrients by the plant-growth-promoting and biocontrol fungus Trichoderma harzianum Rifai 1295-22. Appl. Environ. Microbiol. 1999, 65, 2926-2933. [CrossRef]

83. Li, R.-X.; Cai, F.; Pang, G.; Shen, Q.-R.; Li, R.; Chen, W. Solubilisation of phosphate and micronutrients by Trichoderma harzianum and its relationship with the promotion of tomato plant growth. PLoS ONE 2015, 10, e0130081. [CrossRef]

84. Illmer, P.; Schinner, F. Solubilization of inorganic calcium phosphates-Solubilization mechanisms. Soil Biol. Biochem. 1995, 27, 257-263. [CrossRef]

85. Kredics, L.; Manczinger, L.; Antal, Z.; Pénzes, Z.; Szekeres, A.; Kevei, F.; Nagy, E. In vitro water activity and $\mathrm{pH}$ dependence of mycelial growth and extracellular enzyme activities of Trichoderma strains with biocontrol potential. J. Appl. Microbiol. 2004, 96, 491-498. [CrossRef]

86. Kuzmanovska, B.; Rusevski, R.; Jankulovska, M.; Oreshkovikj, K.B. Antagonistic activity of Trichoderma asperellum and Trichoderma harzianum against genetically diverse Botrytis cinerea isolates. Chil. J. Agric. Res. 2018, 78, 391-399. [CrossRef]

87. Bonaterra, A.; Camps, J.; Montesinos, E. Osmotically induced trehalose and glycine betaine accumulation improves tolerance to desiccation, survival and efficacy of the postharvest biocontrol agent Pantoea agglomerans EPS125. FEMS Microbiol. Lett. 2005, 250, 1-8. [CrossRef] [PubMed]

88. Živković, S.; Stojanović, S.; Ivanović, Ž.; Gavrilović, V.; Popović, T.; Balaž, J. Screening of antagonistic activity of microorganisms against Colletotrichum acutatum and Colletotrichum gloeosporioides. Arch. Biol. Sci. 2010, 62, 611-623. [CrossRef]

89. Jegathambigai, V.; Wijeratnam, R.W.; Wijesundera, R. Effect of Trichoderma sp. on Sclerotium rolfsii, the causative agent of collar rot on Zamioculcas zamiifolia and an on farm method to mass produce Trichoderma species. Plant Pathol. J. 2010, 9, 47-55.

90. Figueirêdo, G.S.d.; Figueirêdo, L.C.d.; Cavalcanti, F.C.N.; Santos, A.C.d.; Costa, A.F.d.; Oliveira, N.T.D. Biological and chemical control of Sclerotinia sclerotiorum using Trichoderma spp. and Ulocladium atrum and pathogenicity to bean plants. Braz. Arch. Biol. Technol. 2010, 53, 1-9. [CrossRef] 